\title{
미국 해외 긴급재난구호 시스템
}

1. 해외재난 발생시 정부내 지원업무 총괄, 조정 및 이행 체계

ㅁ 국제개발처(USAID)가 총괄기능 수행

- USAID내 "Bureau for Democracy, Conflict and Humanitarian Assistance" 아래 OFDA(Office of US Disaster Assistance)가 실무부서

ㅁ OFDA는 여타 USAID 부서, 국무부, 국방부 등 관련부처와 긴밀히 협력하여 지원규모를 결정하 고 집행

ㅁ 참고 : 국무부내 국제재건안정조정관실(S/CRS)은 일반적인 해외 긴급 재난구호 업무에는 관여하지 않고, 정변, 테러 사태 등 위기상황 발생시에만 전 체 미정부의 지원업무를 총괄

2. 해외에 파견되는 긴급구호대 편성 및 파견절차

ㅁ 우선 현장조사단(DART: Disaster Assistance Response Team)을 파견, 상황 파악 및 지원필요
사항 파악

- 먼저 현장 인근의 해외 USAID 사무소에서 현 장에 직원을 급파하고 필요시 본부에 지원인력 을 요청

DART의 평가에 기초하여 본국에서 긴급구호대 파견(DART는 필요한 구호대 파견과 아울러 전체 지원규모에 대해서도 건의)

- USAID는 매 5 년마다 2 개의 지방정부 구호대와 협력약정을 맺고, 해외 긴급구호대 파견시 동 인력을 급파-현재 USAID가 약정을 맺고 있는 기관은 Fairfax County와 Los Angeles County 구호대인 바, 해외구호대 파견시 $\mathrm{USAID}$ 긴급구호 예산으로 동 기관에 필요 비 용지불)

ㅁ 파견되는 구호대는 이미 FEMA(연방재난관리청) 에서 특별히 교육된 인력으로 구성 
3. 민간단체에 대한 지원 여부 및 피해발생시 보 상제도

ㅁ $\mathrm{OFDA}$ 는 필요시 $\mathrm{NGO}$ 에 예산을 지급하여 특정 원조활동을 하청하고, $\mathrm{NGO}$ 의 동 업무수행 과정 을 모니터링

- 아울러 필요시 $\mathrm{OFDA}$ 는 개별적으로 인력을 고 용하여 원조활동 수행

무호활동 조사 민간인 피해발생시 USAID가 직접 고용계약을 체결한 경우에만 보상하며, 그 외에는 개인 또는 $\mathrm{NGO}$ 가 자체적으로 위험 부담

\section{4. 해외재난 지원예산 확보 방식}

USAID 내에 국제재난 및 기아원조 예산항목 보유 -2004년 551천불, 2005년 309천불, 2006년 235 천불 등

대형재난 발생시 미정부는 별도로 원조서약 (pledge)을 하며, OFDA는 동 의회승인을 얻은 예 산을 집행
5. 해외 긴급재난구호 관련법

ㅁ 1961년 제정된 “해외원조법(Foreign Assistance Act)" 9장(Chapter 9)에 해외재난구호 관련사항 을 명시

- 동 법에 의거 미 대통령은 USAID 처장을 해외재 난원조 특별조정관으로 지정

[자료:주미국 대사관] 